\title{
Assessment of the Activities of Scavengers in Obio/Akpor Local Government, Rivers State, Nigeria
}

\author{
Elenwo Ephraim Ikechukwu \\ Department of Geography and Environmental Management, Faculty of Social Science, University of Port \\ Harcourt, Choba, Nigeria \\ Email: iyke2 elenwo@yahoo.com
}

Received 24 January 2015; accepted 26 March 2015; published 30 March 2015

Copyright (C 2015 by author and Scientific Research Publishing Inc.

This work is licensed under the Creative Commons Attribution International License (CC BY). http://creativecommons.org/licenses/by/4.0/

c) (7) Open Access

\section{Abstract}

This study was carried out based on consistent observations on the activities of scavengers of scrap metal in Obio/Akpor local government Rivers State. The study was carried out to ascertain the profitability of scrap metal scavenging and how scrap metal waste can generate wealth to the public and the government. The study made use of primary and secondary data with the former being the main focus. The data were analyzed using the simple percentage, while the hypothesis was tested by means of the chi-square. The study findings revealed that there was a relationship between waste and wealth in relation to scrap metal scavenging. The researches therefore make the following recommendations; that scavengers should form co-operatives so that they can pull their efforts and resources together and bargain collectively. Government and nongovernmental organization should enlighten them through seminars, workshops, etc., on how to carry out their activities in an environmentally safe manner. The state government should encourage scavenging by enacting a law to back the profession and make it attractive for the teaming youths to venture into.

\section{Keywords}

Assessment, Activities, Scavengers, Obio/Akpor

\section{Introduction}

Wastes are things we consider as unfit, unwanted and discarded due to economic reasons or ignorance of alternative technologies to re-use them [1]. It can also be seen as solid, liquid or gas. Waste could also be defined as 
things that could be discarded as useless but that has a potential of causing death, illness or injury to people or destruction of the environment if improperly treated, stored, transported or discarded [2].

According to [1], waste can be defined as substance and materials, which are disposed off according to the provision of national Law. In the same vein, Oxford Dictionary defines wastes as that which is not or cannot be used or no longer in use. In essence, waste materials if not well managed, could result to serious hazards. The generation of solid waste is as old as man's creation and activities. The problem of solid waste is one of the most serious environmental problems facing the world at large. According to [3], he observed that in recent years solid waste generation in metropolitan cities had increased extraordinarily. According to him, the problem of waste can be linked to the fact that population is on the increase and the rate of consumption by various individuals increases by the day, which on the other hand has led to an increase in the amount of waste generated. Solid waste constitutes a major urban environmental paralysis; a clog on the wheel of progress in terms of urban environmental purity and sanitation [4]. Solid waste causes pollution and contributes to global warming which in turn has a negative impact on man and environment. The presence of undisposed waste in a place causes different types of diseases, filth and unsightliness of the environment which affect the lives of human, animals and aquatic organisms.

\subsection{Statement of Problem}

The management of solid wastes has become one of the greatest challenges facing State, local governments and environmental protection agencies in Nigeria. The volume of solid wastes generated continues to increase at a faster rate than the ability of the agencies in Nigeria to surmount. The lack of ability of the agencies to improve on the financial and technical resources needed to parallel the rate of generation is an issue. The deterioration of the urban environment in terms of irresponsibly dumped and accumulated solid wastes is most apparent in our urban lives and has caused a blighted environment [4].

In Obio/Akpor local government, waste has become problematic because of its visibility at major roads in the local government and the degradation of the environment. In most areas in the local government, it is common site to find heaps of waste in many places, besides those wastes that are scattered in gutters, street corners and road sides.

In some cities in Nigeria including Port Harcourt and Obio/Akpor local government, the volume of solid waste generated has over whelmed the urban administrator's capacity to plan for their collection and disposal. These wastes as earlier stated ranges from food materials, sachet water bags, plastic bottles, metals of all categories, demolitions, debris from trees etc. This paper focuses on the activities of scavenger of scrap metals which constitute huge quantity of the volume of waste generated in the local government and how it could be converted to wealth for their livelihood.

In Nigeria, the issue of metal scraps has become a serious business since the demand for it has increased especially for the purposes of recycling and for use in building construction. The business of sale of scrape metals has become a huge source of income for scavengers due to its increasing demand by metal recycling companies. Furthermore, scrap metal waste collection centers are springing up in the local government as well as most cities in Nigeria. Their main purpose is to segregate those materials i.e. (Metals) which could be assembled for recycling which in turn generates huge income to them after sale. It is in the light of the foregoing that this research wishes to investigate the activities of scavengers of scrap metal waste in Obio Akpor local government Rivers State.

\subsection{Recycling of Scrape Metals}

Recycling is a process to change waste materials into new products to prevent making useless of potentially useful materials. Recycling has been a common practice since human history, with recorded advocates as far back as Plato in 400BC. During periods when resources were scarce, archaeological students of ancient times were interested in such waste such as, broken tools and pottery, implying that waste was being recycled in the absence of new materials [5].

In pre-industrial times, there was evidence of scrap bronze and other metals being collected from Europe and melted down for perpetual reuse [5]. In Britain, dust and ash from wood and coal fires were collected by "dust men" and cycled as a base material used in brick making. The main driver for those types of recycling was the economic advantage of obtaining recycled feed stock instead of acquiring virgin material as well as a lack of public waste removal in ever increasing population of the area [5]. 
In 1813, Benjamin law developed the process of turning rags into "shoddy" and "mango" wool in Bartley Yorkshire in the United Kingdom. This material combined recycled fibers with virgin wool. The West Yorkshire shoddy industry in towns such as Batley and Dewsbury lasted from the early $19^{\text {th }}$ century to at least 1924 . Industrialization spurred demand for affordable materials, aside from rags, ferrous scrap metals were converted as they were cheaper to acquire than was virgin ore. Rail road's both purchased and sold scrap metal in the $19^{\text {th }}$ century and the growing steel and auto mobile industries purchased scrap in the early $20^{\text {th }}$ century. Many secondary goods were collected, processed, and sold by peddlers who combed dumps, city streets and went door to door looking for discarded machinery, pots, pans and other sources of metal.

By World War 1, thousands of such peddlers roamed the streets of American cities, taking advantage of market forces to recycle post consumer materials back to industrial production [3]. Beverage bottles were recycled with a refundable deposit by some drink manufacturers in Great Britain and Ireland. An official recycling system with refundable deposits was established in Sweden for bottles in 1884 and aluminum beverage cans in 1982, by law, leading to a recycling rate for beverage containers of $84 \%-99 \%$ depending on type and average use of a glass bottle is over 20 refills [3].

\subsection{Scrap Iron Recycling}

Typically scrap ferrous metal are generated at house hold, auto mechanic workshops and other commercial ventures. Below is a simple diagram to illustrate how scrap iron is generated in the local government.

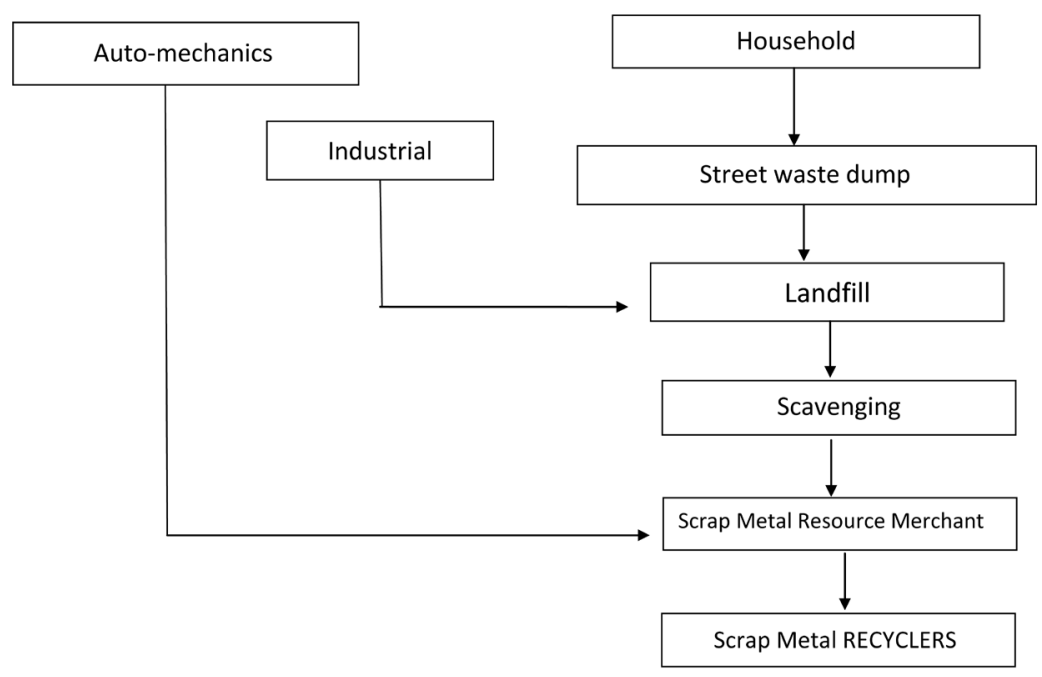

Diagram showing Scrap iron generation in Obio/Akpor LGA, Rivers State, Nigeria, adapted from [6].

\section{Methodology}

The sampling technique adopted in the study is the simple random sampling technique. It was applied on the population of the study area as given by [7]. The area includes Choba, Eliozu, Rumuokoro, Rumuodumaya, and Rumuolumeni communities. In each of these communities, scrap metal collection centers were chosen using the random sampling method in which five communities were selected from the three (3) zones and three (3) centers from each community as shown in Table 1. Furthermore to derive the sample size, the statistical formula by [8] was applied. At the end the population size was reduced to a manageable size of 180 for questionnaire administration. The formula is thus $\mathrm{n}=\mathrm{N}$.

$$
1+\mathrm{N}(\mathrm{e})^{2}
$$

where $\mathrm{n}=$ sample size;

$\mathrm{N}=$ total population;

$1=$ constant;

$\mathrm{e}=$ level of significance $(0.005)^{2}$. 
Table 1. Selection of scrap collection centers in the study area.

\begin{tabular}{cccc}
\hline S/N & Location of collection centers & Number of scrap center sampled & Number of questionnaire administered \\
\hline 1 & Choba & 3 & 36 \\
2 & Rumuokoro & 3 & 36 \\
3 & Rumuodumaya & 3 & 36 \\
4 & Eliozu & 3 & 36 \\
5 & Rumuolumeni & 3 & 36 \\
& Total & 15 & 180 \\
\hline
\end{tabular}

Field Research 2014.

\subsection{Nature of Data Collection}

The data used for this research includes the primary and secondary data. The primary data was obtained using various techniques such as questionnaire administration, field survey and oral interviews. The secondary sources were obtained from the library, available literatures, which includes review of previous work done on the area etc. According to [9] a World Bank report revealed that about $2 \%$ of the third world population survives through scavenging. He further asserts that in Bangkok, Jakarta, Karachi and Manila, that the scavengers save the city at least \$3 million yearly. Questionnaire administration was carried out by means of face to face interview using well structured dichotomous questions which addressed the issues at hand. A total one hundred and eighty (180) questionnaire were administered in the study area. Oral interviews include face to face discussion with the scavengers' themselves at each of the centers in the five communities sampled. This was aimed to elicit salient information on their activities. The information received form part of the opinion on the recommendations made by the researcher in this paper.

\subsection{Method of Data Analysis}

The analytical technique used in the analysis of data for this research is the Chi Square other descriptive statistics used includes tables, frequencies, and charts respectively.

In this case the Chi Square formula is given by equation

where $O=$ Observed frequency;

$$
X^{2}=\sum \frac{(O-E)^{2}}{E}
$$

$E=$ Expected frequency.

\section{Results}

\section{Characteristics of Scavengers}

Various characteristics of scavengers were included in the questionnaire and analyzed. These characteristics were age, sex, educational status, number of years in the business, place of origin, estimated income generated by scavengers etc.

In Table 2 sex of respondents and Table 3 age of scavengers, Figure 1 as cited in the text corroborates the assertion in Table 2. The age and the sex structure of scavengers show that $100 \%$ are males and $0 \%$ is females. In the age structure, most scavengers are at the peak of their productive years that is between 20 - 30 years of age which has $52.6 \%$ response in the sample. This is so because scavenging is labour intensive and females are not involved. Age is another indicator that determines the capacity of this type of profession because the work is for youths and not the elderly who may not withstand the stress of scavenging which involves movement from one waste dump to another searching for waste products of interest. This is corroborated in the Figure 2 as cited in the text.

In terms of educational status of scavengers, it can be shown in Table 4 and Figure 3 that $59.8 \%$ have no formal education, while $27.6 \%$ have only primary education, $12.1 \%$ have secondary education and no person has tertiary education. From this analysis, it is obvious that majority of scavengers are not educated. 
Table 2. Sex of scavengers.

\begin{tabular}{ccccccccccccc}
\hline \multirow{2}{*}{ Sex } & \multicolumn{2}{c}{ Choba } & \multicolumn{2}{c}{ Eliozu } & \multicolumn{2}{c}{ Rumuokoro } & \multicolumn{2}{c}{ Rumuodumaya } & \multicolumn{2}{c}{ Rumuolumeni } & \multicolumn{2}{c}{ Row Total } \\
\cline { 2 - 12 } & $\mathrm{N}$ & $\%$ & $\mathrm{~N}$ & $\%$ & $\mathrm{~N}$ & $\%$ & $\mathrm{~N}$ & $\%$ & $\mathrm{~N}$ & $\%$ & $\mathrm{~N}$ & $\%$ \\
\hline Male & 36 & 20 & 36 & 20 & 36 & 20 & 36 & 20 & 36 & 20 & 180 & 100 \\
Female & - & & - & & - & & - & & - & & - \\
Column Total & 36 & 20 & 36 & 20 & 36 & 20 & 36 & 20 & 36 & 20 & 180 & 100 \\
\hline
\end{tabular}

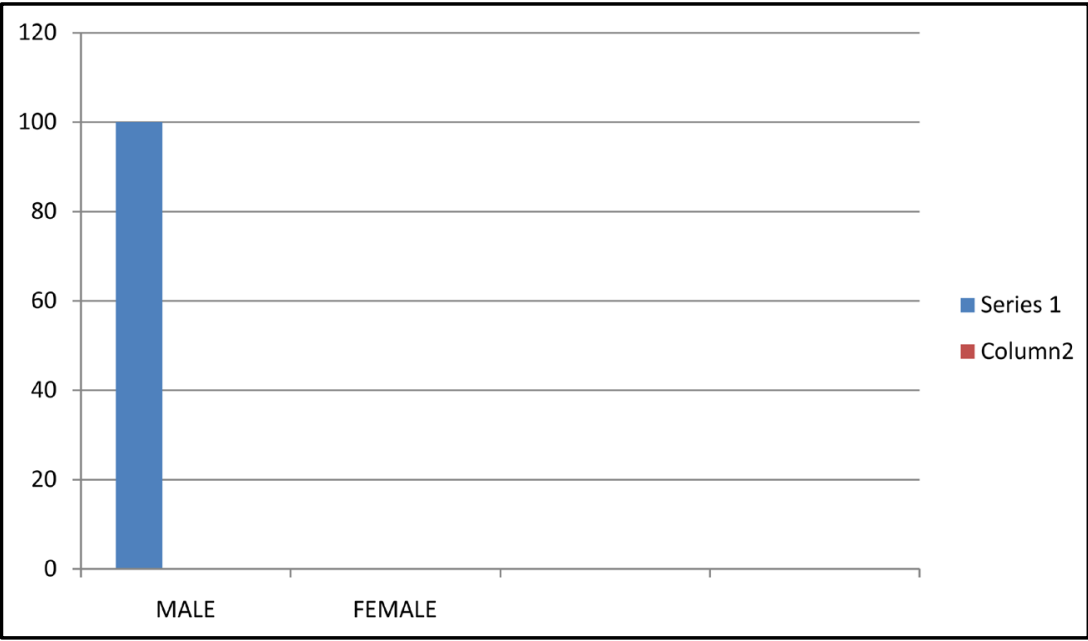

Figure 1. Sex of scavenge. Source: Field Survey, 2014.

Table 3. Age of scavengers.

\begin{tabular}{|c|c|c|c|c|c|c|c|c|c|c|c|c|}
\hline \multirow{2}{*}{ Age } & \multicolumn{2}{|c|}{ Choba } & \multicolumn{2}{|c|}{ Eliozu } & \multicolumn{2}{|c|}{ Rumuokoro } & \multicolumn{2}{|c|}{ Rumuodumaya } & \multicolumn{2}{|c|}{ Rumuolumeni } & \multicolumn{2}{|c|}{ Row Total } \\
\hline & $\mathrm{N}$ & $\%$ & $\mathrm{~N}$ & $\%$ & $\mathrm{~N}$ & $\%$ & $\mathrm{~N}$ & $\%$ & $\mathrm{~N}$ & $\%$ & $\mathrm{~N}$ & $\%$ \\
\hline 20 - 30 Years & 20 & 11.1 & 20 & 11.1 & 25 & 13.8 & 10 & 5.5 & 20 & 11.1 & 95 & 52.6 \\
\hline 31 - 40 Years & 10 & 5.5 & 10 & 5.5 & 11 & 6.1 & 20 & 11.1 & 16 & 8.8 & 67 & 37 \\
\hline 41 - 50 Years & 6 & 3.3 & 6 & 3.3 & - & - & 6 & 3.3 & - & - & 18 & 9.9 \\
\hline 51 - 60 Years & - & - & & & - & - & - & - & - & - & - & - \\
\hline 60 Above & - & - & & & - & - & - & - & - & - & - & - \\
\hline Column Total & 36 & 19.9 & 36 & 19.9 & 36 & 19.9 & 36 & 19.9 & 36 & 19.9 & 180 & 99.5 \\
\hline
\end{tabular}

In Table 5 and Figure 4, with respect to the number of years in the business, it shows that $68.7 \%$ have been in the business for just 1 - 5 years, while 29.7\% have been in it for 6 - 10 years and 1.1\% for 11 - 15 years. The above analysis signifies that scavenging is new in this part of the world, but it is self sustaining.

The response on the place of origin of scavengers shows that $97.6 \%$ are from other States, while $2.2 \%$ are from the State (Table 6 and Figure 5). The indigenes of Rivers State feel that the business is dirty and dehumanizing, therefore does not get involved.

Table 7 and Figure 6 show that 28.1\% generate $¥ 50,000$ while $60.8 \%$ generate $N 100,000$ from scrap metal sales. This analysis shows that it is a lucrative business which keeps people self employed as well as keeps the local government clean.

Hypothesis: Relationship between volume of scrap metal waste and the amount of money realizable.

$\mathrm{H}_{\mathrm{o}}$ : There is no significant relationship between volume of scrap metal generated and the amount of money realizable. 


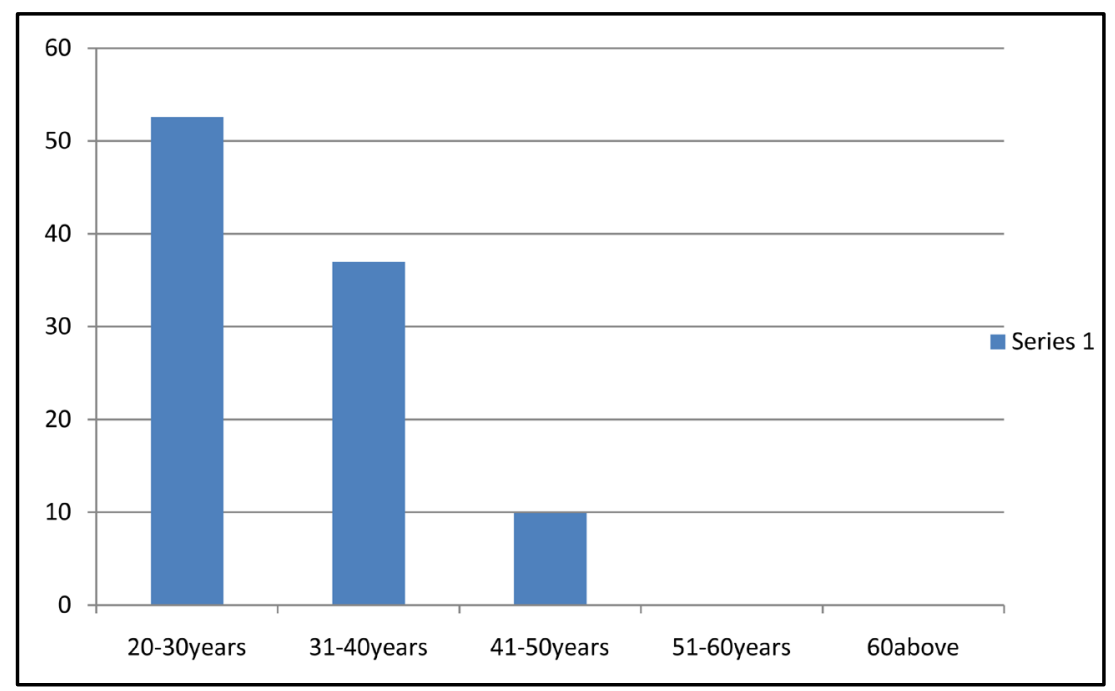

Figure 2. Age of scavengers. Source: Field Survey, 2014.

Table 4. Educational attainments of scavengers.

\begin{tabular}{cccccccccccccc}
\hline & \multicolumn{2}{c}{ Choba } & \multicolumn{2}{c}{ Eliozu } & \multicolumn{2}{c}{ Rumuokoro } & \multicolumn{2}{c}{ Rumuodumaya } & Rumuolumeni & Row Total \\
\cline { 2 - 11 } Educational Level & $\mathrm{N}$ & $\%$ & $\mathrm{~N}$ & $\%$ & $\mathrm{~N}$ & $\%$ & $\mathrm{~N}$ & $\%$ & $\mathrm{~N}$ & $\%$ & $\mathrm{~N}$ & $\%$ \\
\hline No formal Education & 20 & 11.1 & 25 & 13.8 & 15 & 8.3 & 20 & 11.1 & 28 & 15.5 & 108 & 59.8 \\
Primary Education & 6 & 3.3 & 9 & 5 & 15 & 8.3 & 12 & 6.6 & 8 & 4.4 & 50 & 27.6 \\
Secondary Education & 10 & 5.5 & 2 & 1.1 & 6 & 3.3 & 4 & 2.2 & - & - & 22 & 12.1 \\
Tertiary & - & - & - & - & - & - & - & - & - & - & - & - \\
Column Total & 36 & 19.9 & 36 & 19.9 & 36 & 19.9 & 36 & 19.9 & 36 & 19.9 & 180 & 99.5 \\
\hline
\end{tabular}

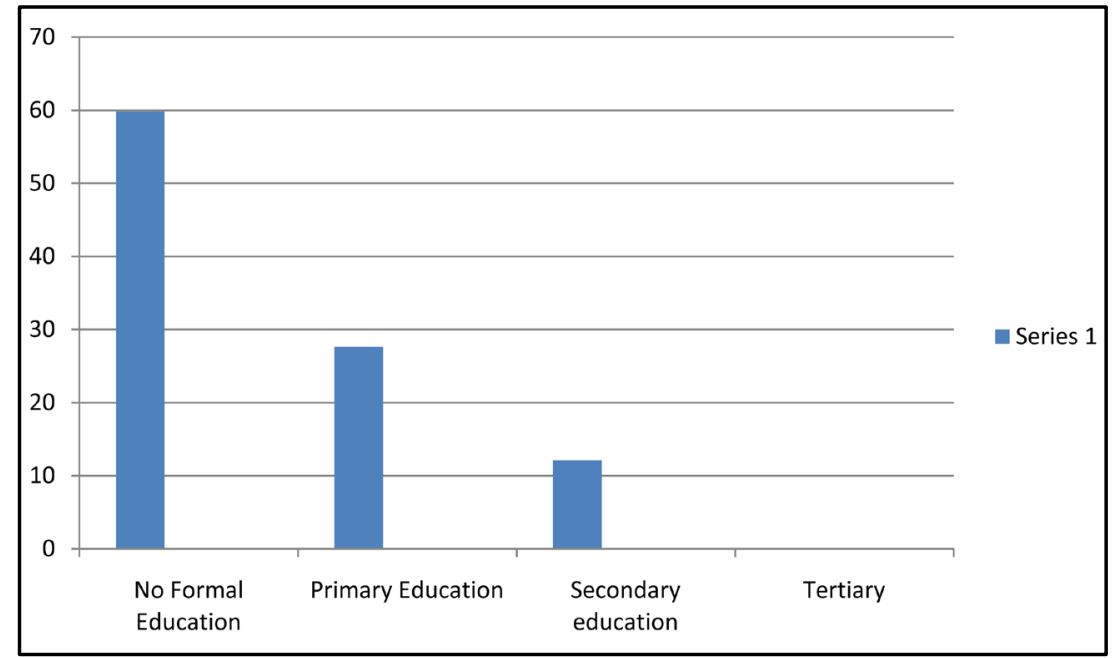

\section{Figure 3. Educational attainments of scavengers.}

Table 8 shows the five sampled communities and their scores and relationship between the scrap metals and the amount realized from the business. The total scores shows $=33.83$ calculated value. Thus, the degree of freedom $=4$. Therefore, the critical value from the chi-square table against 4 degree of freedom at the $95 \%$ probability level $=9.49$. The decision rule thus is; the calculated value of 33.83 is greater than the critical value 
Table 5. Number of years in business.

\begin{tabular}{cccccccccccccc}
\hline \multirow{2}{*}{$\begin{array}{c}\text { Numbers of Years } \\
\text { in the Business }\end{array}$} & \multicolumn{2}{c}{ Choba } & \multicolumn{2}{c}{ Eliozu } & \multicolumn{2}{c}{ Rumuokoro } & \multicolumn{2}{c}{ Rumuodumaya } & \multicolumn{2}{c}{ Rumuolumeni } & \multicolumn{2}{c}{ Row Total } \\
\cline { 2 - 13 }$y$ & $\mathrm{~N}$ & $\%$ & $\mathrm{~N}$ & $\%$ & $\mathrm{~N}$ & $\%$ & $\mathrm{~N}$ & $\%$ & $\mathrm{~N}$ & $\%$ & $\mathrm{~N}$ & $\%$ \\
\hline 1 - 5 Years & 20 & 11.1 & 26 & 14.4 & 28 & 16.6 & 30 & 16.6 & 20 & 11.1 & 124 & 68.7 \\
6 - 10 Years & 16 & 8.8 & 8 & 54.4 & 8 & 4.4 & 6 & 3.3 & 16 & 8.8 & 54 & 29.7 \\
11 - 15 Years & - & - & 2 & 1.1 & - & - & - & - & - & - & 2 & 1.1 \\
Column Total & 36 & 19.9 & 36 & 19.9 & 36 & 19.9 & 36 & 19.9 & 36 & 19.9 & 180 & 99.5 \\
\hline
\end{tabular}

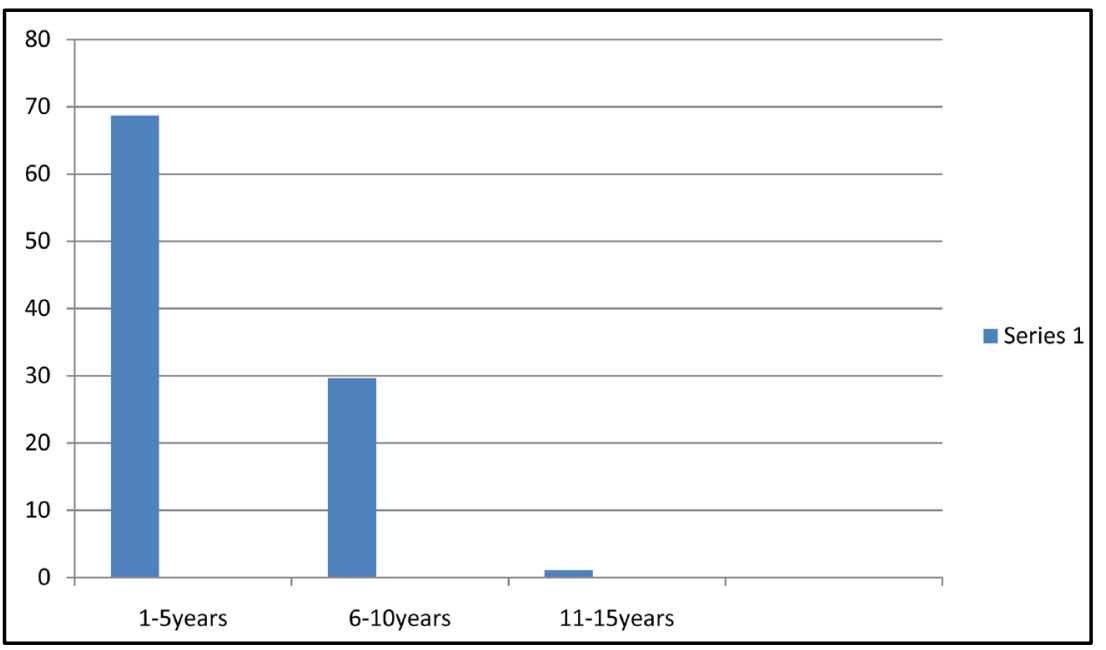

Figure 4. Number of years in business.

Table 6. Place of origin of scavengers.

\begin{tabular}{|c|c|c|c|c|c|c|c|c|c|c|c|c|}
\hline \multirow{2}{*}{ Place of Origin } & \multicolumn{2}{|c|}{ Choba } & \multicolumn{2}{|c|}{ Eliozu } & \multicolumn{2}{|c|}{ Rumuokoro } & \multicolumn{2}{|c|}{ Rumuodumaya } & \multicolumn{2}{|c|}{ Rumuolumeni } & \multicolumn{2}{|c|}{ Row Total } \\
\hline & $\mathrm{N}$ & $\%$ & $\mathrm{~N}$ & $\%$ & $\mathrm{~N}$ & $\%$ & $\mathrm{~N}$ & $\%$ & $\mathrm{~N}$ & $\%$ & $\mathrm{~N}$ & $\%$ \\
\hline Within Port Harcourt & - & - & - & - & - & - & - & - & - & - & - & - \\
\hline From Rivers State & - & - & - & - & 2 & 1.1 & - & - & 2 & 1.1 & 4 & 2.2 \\
\hline Outside Rivers State & 36 & 20 & 36 & 20 & 34 & 18.8 & 36 & 20 & 34 & 18.8 & 176 & 97.6 \\
\hline Non-Nigerian & - & - & - & - & - & - & - & - & - & - & - & - \\
\hline Column Total & 36 & 20 & 36 & 20 & 36 & 19.9 & 36 & 20 & 36 & 19.9 & 180 & 99.8 \\
\hline
\end{tabular}

of 9.49, we therefore reject the null hypothesis and accept the alternate hypothesis, which says that the amount of money realizable from scrap metal is dependent on the volume generated of scrap gathered.

\section{Findings}

The hypothesis tested in the research has highlighted some major findings that the activities of scavengers creates employment and also assist in the cleanliness of the environment. Furthermore, from Table 4, which shows the educational attainment of the scavengers, it revealed that $59.8 \%$ do not have any formal education which is why they carry out the activities without recourse to safety and their health is at risk. Table 7 shows that scavenging is a profession that not only creates employment but also generates income which if encouraged by the government can serve as a source provision of employment for the teaming youths and generation of in- 


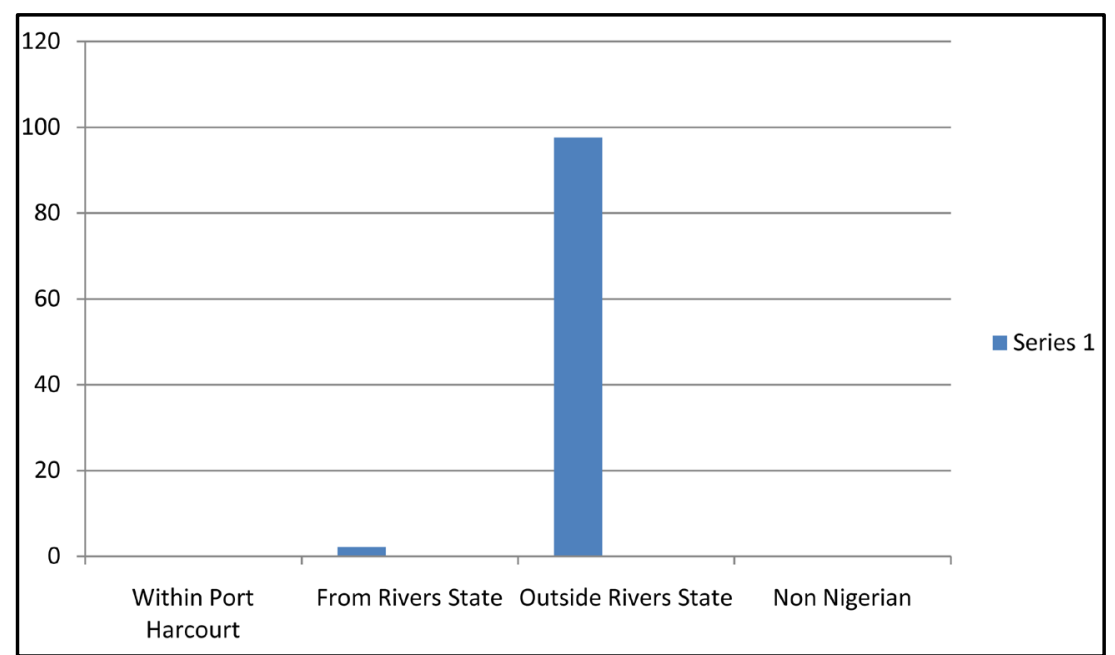

Figure 5. Place of origin of scavengers.

Table 7. Estimated income generated by scavenger per month.

\begin{tabular}{|c|c|c|c|c|c|c|c|c|c|c|c|c|}
\hline \multirow{2}{*}{ Estimated Income } & \multicolumn{2}{|c|}{ Choba } & \multicolumn{2}{|c|}{ Eliozu } & \multicolumn{2}{|c|}{ Rumuokoro } & \multicolumn{2}{|c|}{ Rumuodumaya } & \multicolumn{2}{|c|}{ Rumuolumeni } & \multicolumn{2}{|c|}{ Row Total } \\
\hline & $\mathrm{N}$ & $\%$ & $\mathrm{~N}$ & $\%$ & $\mathrm{~N}$ & $\%$ & $\mathrm{~N}$ & $\%$ & $\mathrm{~N}$ & $\%$ & $\mathrm{~N}$ & $\%$ \\
\hline$\$ 50,000$ & 10 & 5.5 & 5 & 2.7 & 10 & 5.5 & 6 & 3.3 & 20 & 11.1 & 51 & 28.1 \\
\hline$\$ 100,000$ & 25 & 13.8 & 25 & 13.8 & 20 & 11.1 & 30 & 16.6 & 10 & 5.5 & 110 & 60.8 \\
\hline$\$ 150,000$ & 1 & 0.5 & 6 & 3.3 & 3 & 1.6 & - & - & 6 & 3.3 & 16 & 8.7 \\
\hline$\$ 200,000$ & - & - & - & - & 3 & 1.6 & - & - & - & - & 3 & 1.6 \\
\hline$\$ 250,000$ & - & - & - & - & - & - & - & - & - & - & - & - \\
\hline Column Total & 36 & 19.8 & 36 & 19.8 & 36 & 19.8 & 36 & 19.9 & 36 & 19.8 & 180 & 99.2 \\
\hline
\end{tabular}

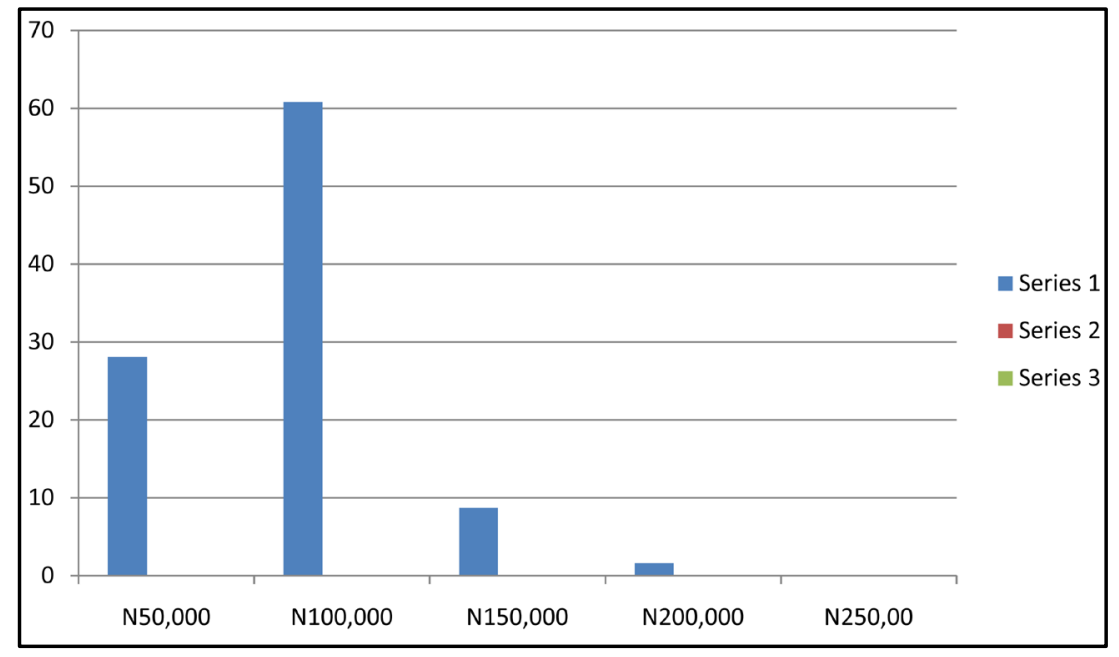

Figure 6. Estimated income generated by scavengers.

ternal revenue to local government, the state and the federal government. The hypothesis test proved that there exist a relationship between the volume of scrap metal waste recycled and the amount of money that can be realized. 
Table 8. Chi-square contingency table test for relationship between volume of scrap metal and amount realized by scavengers.

\begin{tabular}{|c|c|c|c|c|c|c|c|c|c|c|c|c|}
\hline \multirow{2}{*}{$\begin{array}{c}\text { Categories of } \\
\text { Sampled Areas }\end{array}$} & \multicolumn{2}{|c|}{ Choba } & \multicolumn{2}{|c|}{ Eliozu } & \multicolumn{2}{|c|}{ Rumuokoro } & \multicolumn{2}{|c|}{ Rumuodumaya } & \multicolumn{2}{|c|}{ Rumuolumeni } & \multicolumn{2}{|c|}{ Row Total } \\
\hline & N & $\%$ & $\mathbb{N}$ & $\%$ & $\#$ & $\%$ & $N$ & $\%$ & $\mathbb{N}$ & $\%$ & N & $\%$ \\
\hline 1 & 10 & $(10.2)$ & 25 & (22) & 1 & (3.2) & - & - & - & - & 36 & \\
\hline 2 & 5 & $(10.2)$ & 25 & (22) & 6 & (3.2) & - & - & - & - & 36 & \\
\hline 3 & 10 & $(10.2)$ & 20 & (22) & 3 & (3.2) & 3 & - & - & - & 36 & \\
\hline 4 & 6 & $(10.2)$ & 30 & (22) & 0 & (3.2) & - & - & - & - & 36 & \\
\hline 5 & 20 & $(10.2)$ & 10 & (22) & 6 & (3.2) & - & - & - & - & 36 & \\
\hline Column Total & 51 & & 110 & & 16 & & 3 & & 0 & & 180 & \\
\hline
\end{tabular}

\section{Recommendation}

Measures to achieve effective activities of scavengers in scrap metal recycling in the local government and state some recommendations are suggested:

- There should be promulgated a law by the government to encourage scavenging, protection and remuneration so as to make it attractive to the youths.

- That since scavenging provides and benefits our society; it should be supported and not persecuted. The scavengers should be formally recruited by the government to carry out the segregation of solid waste which will reduce the amount of waste that needs to be collected for disposal.

- For those who make their livelihood from collecting, sorting, or otherwise handling waste, measures should be adopted to provide them with the requisite safety.

Protective wears to improve their work environment.

\section{References}

[1] Adeyemi, A.O. (2001) Waste Scavenging in Third World Cities: A Case Study in Ilorin City. An Inaugural Lecture University of Ilorin, Nigeria.

[2] Tchnobauoglous, G., Theisen, H. and Vigil, S. (1993) Evolution of Solid Waste Management in Integrated Solid Waste Management in Perugia. A Research Work on Perugia Italy.

[3] Zimring, CA. (2005) Cash for Your Trash. Scrap Recycling in America. John Wiley and Sons Inc., Hoboken.

[4] Ayotamuno, J.M. and Gobo, A.E. (2004) Municipal Solid Waste Management in Port Harcout, Nigeria. Journal of Environmental Management and Quality, 15, 38-47.

[5] The Truth about Recycling. http://www.economist.Com/opinion/

[6] Black Dog Publishing (2006) Recycle: A Source Book. American Ceramic Society, Westerville.

[7] National Bureau of Statistics (NBS) (1991) Nigeria Population Statistics.

[8] Yamane, T. (1967) Statistics: An Introductory Analysis. 2nd Edition, Harper and Row, New York.

[9] Medina, M. (1997) The World and Scavengers; A World Bank Report on Scavenging for Sustainable Development. UN/84/R-97/002. 